\title{
BAHAISM AND RELIGIOUS ASSASSINATION
}

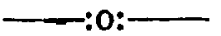

Charaes have been made, in detail, against the companions of Baha Ullah of assassinating the Azalis, the followers of his rival Subh-i-Azal. Most of the information regarding the matter is to be found in the books and translations of Prof. E. G. Browne, of Cambridge University, the greatest authority on Bahaism, at least in the Anglo-Saxon world. I wish to present and weigh the evidence in hand regarding these accusations.

1. The first charge is that Baha Ullah attempted to poison Subh-i-Azal, his half-brother and predecessor. This charge is found in the Hasht Behesht, a history of Babism, by Aga Sayid Javad*, a prominent Mullah of Kirman and a leading disciple of the Bab. The occurrence took place when Azal and Baha were both at Adrianople under surveillance of the Turkish authorities. Baha, so it narrates, $\dagger$ ordered that there should be placed before him and "Azal a dish of plain food, with one side of which he had mixed some poison, intending to poison Azal. For hitherto the apportioned breakfast and supper had been from the house of Mirza Husain Ali (Baha Ullah). When that poisoned dish was placed before them, Baha pressed Azal to take of it. By a fortunate chance, the smell of onions was perceptible in the food, and Azal, being averse to onions, refused to taste it. Though urgently pressed, he refused, saying: 'It smells of onions.' Baha, supposing his evil design was suspected, and to disguise the truth, ate a little from the other (unpoisoned) side in order that Azal's suspicions might be dispelled and that he might eat of the poisoned side.

" "New History," tranclated by Prof. Browne, p. 200, Note 4.

$\dagger$ "Journal of the Royal Asiatic Society," 1892, p. 296, by Prof. Browne. Also "Traveller's Narrative," translated by the same author, p. 359. 
Now, inasmuch as the poison had to some extent diffused itself to the other side, it produced some slight effect on Baha, causing him sickness and vomiting, so that he summoned his physician." This account was confirmed by Mirza Abdul Ali, the son of Subh-i-Azal, to Prof. Browne, when he visited him in Cyprus in 1888.*

The daughter of Baha, Bahiah Khanum, gives a contradictory account of the same affair. $\dagger$ She says that the feast was at Azal's house and that rice for both was served on the same plate, having been prepared in Azal's house. "The portion of rice intended for my father was flavoured with onions, of which he was very fond. The servant, by direction of Azal, placed this portion towards my father. He ate some of it, but fortunately not very much. He preferred the rice prepared for Azal, and ate of it. Soon after eating he became ill. The physician declared that he had been poisoned. He was so desperately ill for twenty-two days that the physician said he could not live." Mirza Abul Fazl, a Bahai writer, says, $\ddagger$ " Azal sought to poison Baha Ullah, and attempted to do so twice, but failed to accomplish his design." "He repeatedly planned to murder Baha." Baha himself alludes to these erents in the Sura-i-Haykal.§ " $\mathrm{My}$ brother warred with me. He desired to drink my blood. He took counsel with one of my attendants tempting him unto this. We went out from among them and dwelt in another house. Neither did we see him afterwards."

Thus we have brother against brother, each accusing the other of attempting fratricide. How shall we settle the question of veracity? Mr. Phelps makes a plea for Baha, but his words lack foundation. He says that Azal's story " is a transparent fabrication hecause it assumes an impossible ignorance on the part of Baha Ullah that Azal disliked onions, as well as the impossible

* "Traveller's Narrative," p. 369.

† Phelps. "Life of Abbas Effendi," pp. 40-44.

+ " Prilliant Proof," p. 11.

" Chicago Edition," pp. 20-23 ; and "Traveller's Narrative," pp. 368,69 . 
hypothesis that Baha Ullah would knowingly partake of food in which poison had been placed." But neither of these "impossible" things are a part of the story. The first objection can only be taken, if at all, to Prof. Browne's abridged account in the "Traveller's Narrative," and not to the original in "Hasht Behesht," which distinctly states that onions had communicated their flavour to the other side of the platter, contrary to intention; and, secondly, Baha supposed when he ate (according to the "Hasht Behesht" account) that the poison had not communicated itself to his side of the platter of rice. Those familiar with Persian pillau, or boiled rice, in which each grain is separate and dry, will see that it would ordinarily be quite possible to put onions and poison on opposite sides of the platter without either reaching the other side. Each man would help himself, according to Persian custom, from the side of the dish next to him. Moreover, it was customary to prepare the food for Azal in the kitchen of Baha.* Up to the time of the incident they had both continued to live in the same house. This is crident from Baha's words in the "Sura-i-Haykal," where he says, "We went out, dwelt in another house, neither did we see him afterwards." This agrees with the "Hasht Behesht." In this and several other particulars the narrative of Bahiah Khanum is defective or misleading. Mr. Phelps' plea, on account of the character of the Bahais, begs the question. This charge and subsequent ones to be discussed, involve the integrity of Baha's character and that of his immediate disciples. The history shows no more reason to believe Baha than to believe Azal, but rather less.

2. The next charge of the Azalis is as followst:"Shortly after this, another plot was laid against Subhi-Azal's life, and it was arranged that Mohammed Ali, the barber, should out his (Azal's) throat while shaving him in the bath. On the approach of the barber, however, Subh-i-Azal divined his design, refused to allow him to come near, and, on leaving the bath, instantly

* Phelps. idem, p. 40. † “Traveller's Narrative," p. 359. 
took another lodging, and separated himself entirely from Mirza Husain Ali and his followers."

On the Bahai side, Bahiah Khanum says,* "One day in the bath Azal asked the servant (of Baha) 'whether it would not be easy for an attendant who was not faithful to Baha to make away with him while shaving him.' The servant replied that this was certainly the case. Azal then asked whether, if God should lay upon him the command to do this, he would obey it? The servant understood this to be the suggestion of such a command, and was so terrified by it that he rushed screaming from the room. This occurrence was ignored by my father, and our relations with Azal continued to be cordial."

Here we have two stories in direct contradiction to each other. It may be observed that the attendant or barber, who was that day serving Azal in the bath, as is agreed by both parties, was a partisan of Baha, $\dagger$ without doubt the same barber, Mohammed Ali, who subsequently murdered the Azalis, $\ddagger$ and who was decorated by Baha with the title Dallak-i-Hakikat,ई "The Barber of the Truth." It was much more natural that Azal should be suspicious of him than try to tempt him to kill Baha.

In either case, what do we see? Behold, these two "Manifestations of God" accusing each other of attempting assassination. They were brothers, both eminent disciples of the Bab, the "Point of Divinity" of the " new Revelation," both "revealers of inspired verses." The heart of each was full of hatred and envy and of desire to over-reach the other. Neither is worthy of credence, both being steeped in Persian deception from childhood. Possibly, at that time, each was ready to compass the death of the other. The subsequent history, however, casts back its reflection upon the murder-plots at Adrianople, and in its lurid light the character of the Bahais grows darker. As a consequence, the charges of the Azalis against the Bahais become probable and are easily accepted.

* Phelps, p. 39. † Idem, p. 38.

‡ "Traveller's Narrative," p. 361. §Idem, p. 362. 
3. The proved assassination of Azalis by Bahais at Acca. The quarrels and plots at Adrianople led to complaints of each party against the other before the Osmanli Government. For the sake of peace and safety they were separated. Azal was sent as a prisonerpensioner to Famagusta, Cyprus. Baha was removed to Acca, Syria. The "Hasht Behesht" says* : "With the latter were his family, about eighty of his adherents, and four of Subh-i-Azal's followers, to wit, Haji Sayid Mohammed of Ispahan, Aga Jan Bey, Mirza Riza Kuli of Tafrish, and his brother Aga Mirza Nasrullah."

These Azalis were murdered by the Bahais in Acca. Of this crime there are many who give testimony. (a) The "Hasht Behesht" sayst: "Before the transfer was actually effected, however, Mirza Nasrullah was poisoned by Baha, at Adrianople. The other Azalis were assassinated shortly after their arrival at Acca, in a house which they occupied near the barracks, the assassins being Abdul Karim, Mohammed the barber, Husain the water-carrier. and Mohammed Javad of Kasvin" (all attachés of Baha).

(b) Subl-i-Azal independently confirmed this account in conversation with Prof. Browne.

(c) Bahai testimony also confirms it. Prof. Browne heard the story at Kirman from Sheikh Ibrahim, a Bahai, who had suffered imprisonment and torture for the faith, and who had seen some of the perpetrators while on a pilgrimage to Acca. He said,§ "The Babis were divided into two factions. So high did feeling run that the matter ended in open strife, and two Azalis and one Bahai were killed," at Adrianople. "The Turkish Government sent seven\| Azalis to Acca with Baha. They-Aga Jan, called Kaj-Kulah, Haji Sayid Mohammed of Ispahan, one of the original companions of the Bab, Mirza Riza, a nephew of the last, Mirza Haydar Ali of Ardistan, Haji Savid Husain of Kashan, and two others whose names I forget-lived all together in a

* "Traveller's Narrative," p. 361. † Idem, p. 361.

Idem, p. 371. \$ “A Year Among the Perisins," pp. 513-517. Baha.

It Possibly he counts those who afterwards left their allegiance to 
house situated near the gate of the city. Well, one night about a month after their arrival at Acca, twelve Bahais (nine of whom were still living when I was at Acca) determined to kill them and so prevent them from doing any mischief. So they went at night, armed with swords and daggers, to the house where the Azalis lodged, and knocked at the door. Aga Jan came down to open to them, and was stabbed before he could cry out or offer the least resistance. Then they entered the house and killed the other six." In consequence, "the Turks imprisoned Baha and all his family and followers in the caravanserai, but the twelve assassins came forward and surrendered themselves, saying, "We killed them without the knowledge of our Master or of any of the brethren. Punish us, not them.' So they were imprisoned for a while; but afterwards, at the intercession of Abbas Fffendi (Abdul Baha), were suffered to be at large, on condition of remaining at Acca and wearing still fetters on their ankles for a time."

(d) Mr. Lawrence Oliphant gives an account of the Bahais at Acca in his "Haifa, or Life in Modern Palestine."* He substantiates the account of the assassinations, and narrates how Baha Ullah was called before the Osmanli Court to answer on the charge of complicity in them. He further states that after one session, Baha "purchased an exemption from further attendance at court, with an enormous bribe."

(e) The defence, unable to escape the force of the damaging testimony or to deny the facts against such testimony, can only offer some excuses in extenuation. Bahiah Khanum $\dagger$ reduces the number of Bahais who made the attack on the Azalis to three, asserts that their intention was to threaten death and frighten but not to kill them, that but two Azalis were killed and also one of the Bahais, that the prorocation was that the Azalis had slandered Baha Ullah, forged letters in his name, which incited the Government against him and were threatening to kill him, and further that Baha

* “Haifa, etc.", p. 107; “"Traveller's Narrative," p. 370.

† Phelps, p. 75. 
was not cognisant of their intention. But Prof. Browne shows that Baha regarded the murder with some complacency at least," and refers to it in the Kitab-ul-Akdas, saying, "God hath taken away him who led you astray," viz. : Haji Sayid Mohammed, one of the murdered men, who was Azal's chief supporter. He also confirms the fact that Abbas Effendi interceded for the murderers and secured their freedom from adequate punishment. Just as Brigham Young $f$ condoned and secured immunity from punishment, if he did not justify or instigate the crimes of his sect, Bahiah Khanum herself shows us that the murderers acted for the religion, and not from any private or personal motives ; in other words, committed "religious assassination," after the traditional oriental custom.

4. Various and sundry other assassinations for the faith. According to the Azali historian, these murders were followed by many others. Certain disciples separated themselves from Baha. Of these some fled from Acca, $\ddagger$ " but the Khayyat Bashi (chief tailor) and Haji Ibrahim were assassinated in the caravanserai of the corn-sellers and buried in quicklime under the platform. Another, Haji Jaffar, importunately pressed his claim for a debt of 1,200 pounds which Baha owed him. (I wonder whether it was incurred to meet the 'enormous bribe.'). Thereupon Baha's amanuensis, "Mirza Aga Jan Kashani instructed a disciple, Ali of Kasvin, to slay the old man and throw his body out of the window of the upper room which he occupied in the caravanserai." It was then reported, " that he had cast himself out and died, yielding up his life to the Beloved." "All the prominent supporters of Subl-i-Azal, who withstood Baha, were marked out for death, $\S$ and in Bagdad, Mullah Rajab Ali Kahir

- "Journal Royal Asiatic Socicty, 1889," p. 519 ; “Traveller's Narrative," pp. 94, 370.

†"Brigham Young," by Camon, p. 271. "Brigham failed to punish or even condemn those criminals who served him too well."

‡ “Trareller's Narrative," p. 362.

\$ "Traveller's Narrative," p. 359. "Juurnal Royal Asiatic Societ.y, 1889," p. $519 ; 1892$, pp. $195-96$. 
and his brother Haji Mirza Ahmad, Haji Mirza Mohammed Riza and several others fell one by one by the knife or the bullet of the assassin." The following others are specified with the place and name of the assassin,* "Aga Sayid Ali the Arab, one of the original 'Letters of the Living,' was killed in Tabriz by Mirza Mustapha of Nirak ; and Aga Ali Mohammed by Abdul Karim; Haji Aga of Tabriz met a like fate, as did Haji Mirza Ahmad, the brother of the historian Haji Mirza Jani. $\dagger$ Another, whose faith had grown cold, was Aga Mohammed Ali of Ispahan, who was residing at Constantinople. $\ddagger$ Mirza Abul Kasim was sent from Acca with instructions to "bleed that block of heedlessness whose blood is in

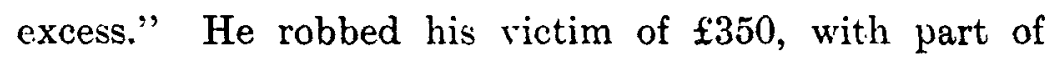
which he bought and sent goods to Acca. Another instance was Mirza Asad Cillah "Deyyan," who claimed

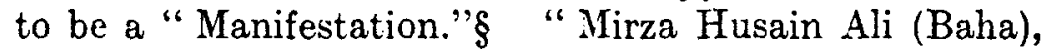
after a protracted discussion with him, instructed his servant, Mirza Mohammed of Mezanderan, to slay him, which was accordingly done." Count Gobineau confirms this account.| Concerning these crimes we have also the independent testimony of Subh-i-Azal. who mentioned most of these instances by name and added several others. Azal said to Capt. Young, a British officer in Cyprus, 9 "About twenty of my followers were killed by the Bahais." $\mathrm{He}$ confirmed it in an autograph letter to Prof. Browne, saying, "They (i.e., the Bahais) unsheathed the sword of hatred and wrought what they would. They cruelly put to death the remnant of my friends who stood firm:" In the "New History"*** Prof. Browne names over the list of those assassinated, and adds, "Of the more prominent Azalis, Sayid Javad, of Kerbela (or Kirman), scems to have been almost the only one who long survived what the Azalis call "The direful Disorder." In Kirman, Prof. Browne said to

* "Traveller's Narrative," p. 363.

† Idem, p. 332. Also "New History," p. 391.

$\ddagger$ "Traveller's Narrative," p. 363 . \. Idem. pp. 357, 365.

" "Religions et Philowophies dinns l'Axie Centrale," pp. 277-278.

- "Journal Royal Asiatic Socict! 18s9," p. 996. ** P. sxiii. 
the Bahais,* "From a statement of one of your own party, it appears that your friends at Acca, who complain so much of the bigotry, intolerance and ferocious antagonism of the Mohammedans, and who are always talking about 'consorting with men of every faith with spirituality and fragrance,' could find no better argument than the dagger of the assassin wherewith to convince the unfortunate Azalis."

5. The conduct of the primitive Babis and their leaders, and their attitude towards the talking of life, has a bearing on the question of the conduct of the Bahais, for up to the time of the residence at Adrianople they were identical. The history of the Babis is a bloody one. The "first blood-shed which took place in Persia (in connection with the Babi movement) was the murder of a Shiah Mujtihid by one or more Babis." It was a "religious assassination." The circumstances were as follows, $\uparrow$ When the $\mathrm{Bab}$, as captive, passed through Kasvin, en route for Maku, he wrote a letter asking succour from Haji Mohammed Taki, an orthodox Mujtihid, who was the father-in-law of the celebrated Kurrat-ul-Ayn. "The Haji tore the letter into fragments, and made some unseemly remarks." When this was reported to the Bab, he said, "Was there no one to smite lim on the mouth ?" The Bahai historian (1880) continues, "Wherefore the Lord brought it to pass that he was smitten in the mouth with a spear head that he might no more speak insolently." Shortly afterwards a certain Babi, $\ddagger$ named Salih, hearing the Mujtihid curse and revile Sheikh Ahmad, the teacher of the Bab, entered the mosque and slew him at the pulpit. The Bahai historian continues, "This was the consequence of the Haji's conduct to the Bab, and agreeable to the tradition

* "A Year Among the Persians," p. 530.

$\dagger$ “New History," pp. 274, 75 ; “Traveller's Narrative," pp. 311, 198,99

‡ The Kasas-ul-Ulema, the Shiah history, says, "Certain Babis, stung by his words, fell upon him early one morning as he was praying in the mosque, and with knives and daggers inflicted on him eight wounds from which he died two days later." - "Traveller's Narrative," p. 198. 
of the Imams, 'whosoever curseth us . . . is an infidel,' and so he deemed it incumbent on himself to slay him."

A variation of this story is found in a work by an American Bahai, Mary H. Ford, called "The Oriental Rose."* She narrates that Kurrat-ul-Ayn heard the Mujtihid cursing the Bab, and gazing upon him she exclaimed, "How unfortunate you are ! For I see your mouth filled with blood!" "The following morning, as he was crossing the threshold of the mosque, he was struck upon the mouth by the lance of a hidden assailant. The attack was followed up by five or six other assassins, who beat the life out of his mangled body." "The strange insight of Kurrat ul-Ayn had foreseen it." "The assassination removed a serious obstacle from her pathway."

From these narratives, both from the pens of "Friends," it is evident that the Bab and Kurrat-ul-Ayn each spoke words which were direct instigations and incitements to their fanatical followers to commit murder. The chief murderer fled and " joined himself to the people of God" at Sheikh Tabarsi. Disregarding his crime, they welcomed him to their ranks as a "follower of God, and he attained to martyrdom. $\dagger$

We can admire the courage and devotion of the Babis, but certainly their hatred and fanaticism carry them on to retaliation and revenge which are far from pure religion. Witness their deeds! Farrukh Khan, a prisoner of war, was first skinned alive and then roasted, $\ddagger$ and twenty-two prisoners of war were put to death at the same time, at Zarjan. At Sheikh Tabarsi, by order of Janab-i-Kuddus, His Excellency the Holy, the enemies slain in battle were decapitated and their heads set on posts around the ramparts. $\S$

The attempt to assassinate Nasr-i-Din Shah (1852) shows also the murderous spirit of the Babis. From seven to twelvel! Babis were engaged in the plot, and

"Pp. 61, 62. + "New History," pp. 278 and 82.

$\ddagger$ Idem, p. 115 and note, p. 411.

"New History," p. 73. “'Truveller's Narrative," p. 178.

IIdem, p. 323. 
four of them started out to take part in the assault. It was not, as is commonly represented by Bahais, the act of an unbalanced, weak-minded individual, but the revengeful plot of a number. The spirit of vengeance was very strong within them. Of this we have a witness from a very unexpected quarter, namely, the celebrated Bahai apologist, Mirza Abul Fazl. He writes,* "Numerous historical and tangible evidences can be furnished to prove that it was the pen of Baha Ullah which protected from death his own enemies, such as Subh-i-Azal, Nasr-i-Din Shah and certain great doctors and divines. Otherwise the Babis would not have allowed a single one of these people to have escaped alive." He certainly must include Bahais, for the Babis would not have desired to kill Sabh-i-Azal.

6. But the assertion of M. Abul Fazl, that Baha was as the "Prince of Peace" among a lot of untrained, untamed disciples, will not stand investigation. For Baha's history shows the contrary. Baha, together with Azal, started for and tried to join the army at Tabarsi, $\uparrow$ and was absent from participation in its sanguinary conflict, solely because his arrest by the Persian authorities at Amul prevented him from reaching the fort. After his release he fell under suspicion because $f$ he " not improbably harboured designs of setting up a standard of revolt on his own account." He was, therefore, rearrested and sent to the capital. One of Baha's Tablets $\S$ is a pæan of exultation on the occasion of the death of Fuad Pasha, the vizier, who exiled him. He rejoicingly celebrates his death and consigns him to Hell, where the heart boils and the tormenting angel melts him and taunts him, saying, "This is Hell, which thou wert wont to deny night and day." Baha also commends suicide for his sake. It is narrated by Abdul Baha \| that rather than be separated in exile from Baha, "Haji Jafar was moved to lamentation, and with his own hand

" "The Brilliant Proof," p. 11.

$\dagger$ "New History," pp. 378, 79. $\ddagger$ Idem, 378-380.

§ "Journal Royal Asiatic Society, 1892," p. 271.

|| “"Traveller's Narrative," pp. 100-101 
cut his throat." Baha, in the Lawh-i-Raiz, alluded to this event, saying, "One from amongst the Friends sacrificed himself for myself and cut his throat with his own hand for the love of God. This is such that we have not heard from former ages. This is that which God hath set apart for this dispensation." Another disciple attempted suicide about the same time.*

These instances are cited as proofs of the truth of the religion, by M. Mohammed Husain Shirazi, who says, $\uparrow$ "More faithful and devoted (than the early Christians), some martyrs of our day have killed themselves with their own hands out of devotion to their Lord Baha." Again Baha sent Badi, the messenger, to the Shah, with the "Epistle" from Acca, assuring him beforehand that he was going to death. The letter could easily have been sent through one of the foreign consulates without sacrifice of life.

7. Psychological attestation of the accusation against the Bahais, of assassination, is seen in their doctrine of the power and prerogative of the "Manifestation," and the inference made by the Bahais from that doctrine. This is set forth in the Tablet of Ishrakat, $t$ "Verily He (Baha) hath come from the Heaven of the Unseen, and with $\mathrm{Him}$ the standard of ' $\mathrm{He}$ doeth whatsoever $\mathrm{He}$ willeth,' and the hosts of power and authority. As to all else save Him: It is incumbent upon them to cling unto that which he hath commanded." "Woe unto those who denied and turned away from Him." "The Most Great Infallibility" is applied only to one (the Manifestation), whose station is sanctified above commands or prohibitions. He is proof against error. Verily if he declares heaven to be earth, right to be left, or south to be north, it is true, and there is no doubt of it." "No one has a right to oppose him, or to say, "Why or wherefore'; and he who disputes Him is verily of the opposers." "He doeth whatsoever he willeth, and commandeth whatsoever he desireth."

In like manner Abdul Baha states the authority of

- Phelps, p. 50. † “Facts for Behaists," p. 42.

$\ddagger$ “Chicago Edition, 1908," pp. 11-14. 
the Manifestation,* " $\mathrm{He}$ is not under the shadow of the former laws. Whatever he performs is an upright action. No believer has any right to criticise." "If some people do not understand the hidden secret of one of his commands or actions, they ought not to oppose it."

These principles are boldly interpreted and applied by the Bahais to the subject under discussion. Sayid Kamil, a Bahai of Shiraz, said to Prof. Browne with a look of supreme surprise, "You surely cannot pretend to deny that a prophet, who is an incarnation of the Universal Intelligence, has a right to inflict death, openly or secretly, on those who stubbornly opposed him. A prophet is no more to be blamed for removing an obdurate opponent than a surgeon for an amputation of a gangrenous limb." This opinion prevailed among the Bahais. At Yezd they said, $¥$ "A divine messenger has as much right to kill and compel as a surgeon to amputate." The Bahai Missionaries maintained $\$$ that, "A prophet has a right to slay if he knows it necessary; if he sees that the slaughter of a few will prevent many from going astray, he is justified in eommanding such slaughter. No one can question his right to destroy the bodies of a few that the souls of many may live." A Bahai acquaintance of Dr. Frame, of Resht, told him\| " without any appearance of shame, that he paid so much to have a persecutor removed."

8. In connection with all the above facts, it must be kept in mind that " religious assassination has been freely practised since the beginning of Islam, and that the prophet Mohammed gave it the sanction of his example on numerous occasions." Prof. Browne, 9 who thus emphasises this fact, and gives instances from the Moslem biographies of Mohammed, points out its bearing on our judgment regarding the assassinations alleged

\footnotetext{
* "Answered Questions," by Barney, pp. 199-201.

† "Traveller's Narrative," p. 372. "A Year in Persia," p. 328.

$\ddagger$ Idem, p. 406.

" Moslem World," 1912, p. 237.

I. "Traveller's Narrative," pp. 371-73.
} 
against the Bahais, and concludes, "In Asia a different standard of morality prevails in this matter." Certain facts regarding the Imams revealed in the dark annals of Islam, show what historical precedents the Babis and Bahais had back of them. Consider the deaths of the twelve Imans. Ali was *assassinated with a dagger, Husain killed after battle, nine other Imams were poisoned, and the last one mysteriously disappeared.

To sum up. Our investigation has led to the conclusion that the Bahais were guilty of these assassinations as charged. The evidence is circumstantial, with names and places. Some of the witnesses are still living. Some have given their testimony in writing, some in conversation with Europeans, who have reported it accurately to the world. The environment in which they lived, and the historical and theological traditions on which they fed, strengthen the direct proofs.

The answer to these charges by Mirza Abul Fazl in his "Brilliant Proof " $\dagger$ is, that we should hear both sides, and that it is not right to accept the witness of enemies against the Bahais, which is as that of Protestants against the Catholics and vice-versâ. Our reply is, that both sides have been heard, and examined, and that some of the most damaging testimony is from Bahais themselves. It should be noted that the testimony is altogether from the followers of the Bab, of various kinds and not from Moslem writers. Mr. Phelps, like many Bahai writers, would ignore the charges. He says, $\neq$ "I do not think that it would be time well employed to advert to them in detail. "He pronounces them "incredible" and "flatly in contradiction to the spirit, lives and teachings of Baha Ullah and his successor," and destined "quickly to fade away and be forgotten, if left to themselves." No indeed! Lovers of truth will not overlook and forget such a record. They will judge Bahais by their deeds, not by their professions.

- "Traveller's Narrative," p. 296.

t A Reply to Rer. P. Z. Easton's article in the " Evangelical Christendom."

$\ddagger$ "Life of Abbas Efs," p. 43. 
The conclusions of Prof. Browne, who was undoubtedly a favourably-inclined judge, who investigated impartially and heard the testimony on both sides, has the greatest weight in determining the judgment of the world. In the "Traveller's Narrative," his first volume on Babism and Bahaism, he states that it is only with great reluctance and solely in the interest of truth, that he sets down these grave accusations against the Bahais, and adds,* " If they are true, of what use are the noblest and most humane utterances, if they are associated with such deeds ? If they are false, further investigation will, without doubt, conclusirely prove their falsity." In the "New History," which was published two years later, after further investigation and calm deliberation, he wrote, $\dagger$ " At first not a few prominent Babis, including even several 'Letters of the Living' and personal friends of the Bab, adhered faithfully to Subh-i-Azal. One by one these disappeared, most of them as, I fear, cannot be doubted, by foul play on the part of too zealous Bahais."

Other defects in morals, the proofs of which I hope to present in a future paper, will add to the conviction that Bahaism stands condemned by the law : "By their fruits ye shall know them."

S. G. WILson. 